Published in "Learned Publishing" vol 23 no 1 pp.69-70 (2010)

\title{
A JOURNAL BUSINESS MODEL TO REPLACE THE BIG DEAL?
}

In the mid-1990s the idea of offering library users a large package of journals at less cost than purchasing subscriptions separately seemed too good an opportunity to be missed, not only for librarians but also for publishers. The advent of the "Big Deal" promised a glorious future for users of journals, for publishers and for librarians. Why has the dream gone sour? As one who has shared and lived through both the euphoria and the scepticism about this particular business model, perhaps I can share some insights, not in order to cast blame (for I may be blaming myself) but in order that lessons may be learned in designing whatever new model for the publication of and access to journal literature is to succeed the Big Deal.

On the negative side (I shall end on a positive note), the Big Deal has had unintended consequences. The cost of acquiring large packages of journals has consumed a larger and larger proportion of academic library budgets year by year, to the point where even the largest academic libraries have very little money left for the purchase of single journal subscriptions or research monographs or student textbooks. Not only has this unintended consequence changed the collection development strategies for academic libraries, but it has made life difficult for users of content not included in Big Deals. Humanities users in particular have lost out through the high expenditure on STM journals. Also losing out have been publishers of content not included in the Big Deals. The Big Deal model has not been a winning formula for the publishing industry as a whole. Another unintended consequence is that the large sums of money committed by libraries to Big Deals have made the Big Deal publishers attractive to investors looking for a secure return upon their investment, leading to mergers amongst those publishers who were seen to be benefiting from the Big Deal model. Those mergers have caused librarians many problems (I shall not go into detail because I promised not to cast blame) and have contributed to the current disillusionment with the Big Deal model.

More positively, alternative models are being considered for reasons other than that the Big Deal has not lived up to its promise of win/win for all stakeholders. Perhaps the most significant factor is that the Big Deal has not proved able to change sufficiently to meet the new opportunities available to users of journals and their librarians. Yes, I know that journal publishers have invested heavily in the electronic format - and users have benefited from that investment - but in many respects electronic Big Deals are proving as restrictive as their print counterparts. It is a truism that the internet and the World Wide Web have changed everything, and have certainly provided researchers with opportunities (such as collaborative text-mining or data-mining) which were not available in the print era. How can the Big Deal model cope with the situation where one research group in an institution with one Big Deal is working collaboratively with a research group in another institution with a different Big Deal? How can researchers collaborate on text-mining when they cannot mine from the same pool of content? We are in a totally fluid information environment, and yet the Big Deal model by its very nature operates with fixed silos of content licensed to particular institutions. The open access model is seen to be much better suited to a fluid information environment because it is barrier-free. The World Wide Web is changing business models as well as everything else about journal publishing and use. 
Before moving on to describe the model I believe will partially or fully replace the Big Deal, it is important to recognise the advantages in the Big Deal model which should not be lost in any change. The Big Deal publishers point to the advantage of a low cost per journal title. To my mind this is not their strongest argument, because it is based upon cost and not upon value or benefit or impact, and is easily countered by arguments which take into account value, benefit or impact in relation to cost. A Big Deal may offer low cost per journal title but many of those titles may be of low academic impact. One significant value the Big Deal offers is in the administrative ease for publishers of supplying and for libraries of purchasing large volumes of content. For both parties this administrative ease releases funds for services of more direct value to the end-user. Another strength of the Big Deal is that it has provided continuity of access to content for end-users. Threeyear deals have been a mixed blessing, but a good feature has been that they have provided publishers with financial confidence, librarians with content confidence (apart from the transfer of journals from publisher to publisher), and users of journals in the Big Deal with access confidence. It will be important to retain this confidence in the future at a time when some are questioning whether the journal itself will survive, let alone the Big Deal.

The challenge facing academia, libraries and the publishing industry is how to change - and change fairly radically - without losing all the benefits the journal literature brings to research, teaching and learning. To many in academia and in libraries, the future has to be predominately an open access future if the opportunities provided by the new technologies are to be realised. And yet it would not be in the interests of the academic and library stakeholders if change happened in a way which caused the collapse of the journal publishing industry. Whatever replaces the Big Deal has to maintain the good features of the Big Deal model, and specifically it must have a viable business model, including low administrative overheads for publishers and libraries. A new model must also offer good value in terms of academic benefit and impact. One model which has the potential to fulfil these criteria is the "gold" open access model with bulk purchase of publication charges. (For open access supporters reading this article, this model is compatible with repository deposit, as it removes the perceived threat to publishers of the "green" route.) The bulk purchase of OA publication charges could be organised either by institutions or by funding agencies or by a national agency, but the key point is to retain the advantage for publishers and for librarians of low administrative overheads. The new model also provides an ongoing role for publishers and librarians, bringing the confidence factor vital in any major change. And last but not least, the model will provide academic benefit for users of journals through the removal of access and use barriers.

This article is not going to conclude with any predictions about the future. The one certainty about predictions is that they are more often wrong than right. The most that can be said is that changes in the world of journals are very likely to continue, and some would say that the changes to come will change the journal even more radically than currently envisaged. As long as researchers, teachers and learners value journals, they will continue in some form, but what they will look like and what the roles of publishers and librarians will be can only be a guess. One change already underway is that priorities will increasingly be driven by universities and funding agencies, with publishers thriving where they provide a service in the new environment. Accountability for public funds now underlies all institutional decisions, and the days are past when universities took no interest in how their research is disseminated and treated journal purchase as a matter to be resolved solely between publishers and librarians. Academic impact and value for money (N.B. not simply a low cost 
per title in a Big Deal) are issues which will drive new business models, and instead of dominating the market the Big Deal will have to compete with newer business models on those criteria.

Fred Friend

Honorary Director Scholarly Communication, UCL

N.B. The views expressed in this article are my own and should not be attributed to any organization with which I am associated. 